\title{
Restitution rights for children of victims of sexual crimes: between protection and reresting
}

\author{
Siti Hudzifah Miftahul Jannah ${ }^{1}$, Syamsuddin Muchtar ${ }^{2}$, Hijrah Adhyanti Mirzana ${ }^{3}$.
}

${ }^{1}$ Siti Hudzaifah Miftahul Jannah; Magister Hukum Universitas Hasanuddin; Jl. Perintis Kemerdekaan KM 10; Makassar; 90245; Indonesia.

${ }^{2}$ Syamsuddin Muchtar; Magister Hukum Universitas Hasanuddin; Jl. Perintis Kemerdekaan KM 10; Makassar; 90245; Indonesia.

${ }^{3}$ Hijrah Adhyanti Mirzana; Magister Hukum Universitas Hasanuddin; Jl. Perintis Kemerdekaan KM 10; Makassar; 90245; Indonesia.

\begin{tabular}{l}
\hline A R T I C L E I N F O \\
\hline Article history: \\
Received 2021-04-09 \\
Received in revised form \\
202107-12 \\
Accepted 2021-08-01 \\
\hline
\end{tabular}

Kata kunci:

Perlindungan Hukum; Restitusi; Anak Korban Kejahatan seksual.

Keywords:

Legal Protection; Restitution; Child Victims of Sexual Crimes.

DOI: $h$ ttps://doi.org/10.26905/ idjch.v12i2.4705.

\section{How to cite item:}

Jannah, SHM., Muchtar, S \& Mirzana, HA (2021). Restitution rights for children of victims of sexual crimes: between protection and reresting. Jurnal Cakrawala Hukum, 12(2), 223-232.

doi:10.26905/idjch.v121i2.4705.

Corresponding Author:

* Siti Hudzaifah Miftahul Jannah.

E-mail address: shmiftahulj@gmail.com

\section{Abstrak}

Kejahatan yang rentan terjadi pada anak-anak salah satunya adalah kejahatan seksual. Kejahatan seksual yang dilakukan pada anak akan berdampak pada psikologis anak, berupa gangguan keadaan mental dan keadaan emosi anak sehingga sudah seharusnya anak yang menjadi korban diberikan perhatian besar atas penderitaan atau kerugian yang dialami dalam bentuk pemberian restitusi dari pelaku. Tujuan dalam penelitian ini untuk mengkaji dan menganalisis bagaimana pemenuhan restitusi bagi anak korban kejahatan seksual dan sejauh mana faktor penegak hukum dan korban berpengaruh dalam pemenuhan hak restitusi tersebut, sehingga untuk menjawab permasalahan tersebut digunakan metode penelitian empiris. Hasil penelitian ini menunjukkan bahwa pemenuhan hak restitusi bagi anak korban kejahatan seksual di kota Makassar tidak terpenuhi, hal ini dibuktikan dengan hanya ada satu kasus dimana korban mengajukan permohonan restitusi dan korban tersebut pun tidak memperoleh restitusi dari pelaku. Penegak hukum dan korban masing - masing memiliki pengaruh dalam pemenuhan hak restitusi. Meskipun demikian, peranan korban memegang pengaruh yang lebih besar, hal ini dikarenakan meskipun penegak hukum yang seharusnya memberitahukan tentang hak restitusi tersebut kepada korban, akan tetapi pihak korbanlah yang memutuskan akan mengajukan permohonan restitusi tersebut atau tidak karena restitusi hanya bisa diperoleh jika korban mengajukan permohonan, tidak otomatis diterima oleh korban. 


\begin{abstract}
One of the crimes that are prone to happen to children is sexual crime. Sexual crimes committed against children will have a psychological impact on the child, in the form of mental and emotional state disorders, so that the child who is the victim should be given great attention to the suffering or loss experienced in the form of restitution from the perpetrator. The purpose of this research is to study and analyze how the fulfillment of restitution for child victims of sexual crimes and the extent to which law enforcers and victims influence the fulfillment of these restitution rights, so that empirical research methods are used to answer these problems. The results of this study indicate that the fulfillment of restitution rights for child victims of sexual crimes in the city of Makassar is not fulfilled. This is evidenced by only one case where the victim submitted a request for restitution and the victim did not get restitution from the perpetrator. Law enforcers and victims each have influence in fulfilling restitution rights. Even so, the role of the victim has a bigger influence, this is because even though the law enforcer should inform the victim about the right of restitution, it is the victim who decides whether to apply for restitution or not because restitution can only be obtained if the victim submits a request. not automatically accepted by the victim.
\end{abstract}

\section{Pendahuluan}

The position of victims in criminal justice as a party of justice seekers has been neglected. Perpetrators receive more attention such as rehabilitation, correctional and others. This is a form of injustice for the victim because as an aggrieved party it is only functioned as a means of proof and it is not uncommon for the human rights of victims to be neglected.

Speaking of victims, in this day and time the most common victim found around is a child. Many children are victims of crime, both minor crimes and even serious crimes (Maya, 2014). Evil has been known since the civilisation of man. The higher civilization, the more rules and more violations (Alam and Amir, 2018).

Making a child a victim of crime, one of the most vulnerable crimes is a sexual crime. Sexual crimes are violence that occur because of the issue of sexuality. The practice can be just harassment, rape, it can also be in the form of sodomy. Children are used as a means of lust for those with this sex disorder (Abdussalam and Adri, 2014).
The last three years seem to be a concerning year for the world of Indonesian children. The Technical Implementation Unit of the Integrated Service Center for The Empowerment of Women and Children recorded cases of child abuse occurring in districts or cities in South Sulawesi during 2016 to 2018 as many as 3,300 cases.

In Makassar in particular, in 2016 there were 34 cases. Meanwhile, in 2017 there were 67 cases and 100 cases in 2018 . The most common case is a sexual crime. Even the most sexual crimes against children are the person closest to the victim (Andi, 2018).

In 2017, government regulation number 43 of 2017 on The Implementation of Restitution for Children Who Are Victims of Crime. In this Government Regulation it is regulated on the right of the child to obtain restitution from the perpetrator because of his or her actions that harm the child, both physically and psychically which causes the child to be unable to perform its functions.

The verdict on restitution itself gained permanent legal force if the criminal verdict also 


\section{Restitution rights for children of victims of sexual crimes: between protection and reresting}

Siti Hudzifah Miftahul Jannah, Syamsuddin Muchtar, Hijrah Adhyanti Mirzana

gained permanent legal force. Restitution requests from victims are directed to perpetrators of crimes. Restitution submitted to the defendant is combined or examined and decided at the same time on the examination and verdict of the criminal case presented to the defendant. Therefore, the process or procedure and substance of restitution arrangements is considered to contain weaknesses.

In practice it is also rare and almost never even done merging this lawsuit. This is partly because the victim does not know his rights, investigators and/or prosecutors do not disclose those rights to the victim, nor does the judge offer this process. So this problem is quite complex (Bambang, 2014).

The next challenge in this restitution application is many ways for criminals to refuse to pay restitution. In current practice, there is no guarantee that restitution can be immediately paid to the victim, which usually happens to be the perpetrator unwilling to pay and unable to pay. There are no rules on the consequences if the perpetrator is unwilling to pay restitution to the victim. With this situation, the victim is still unable to obtain financial compensation (Harris, 2017).

Furthermore, Navira Araya Tueka explained that of the 30 respondents who were victims of crime, only five of them knew about the merger of compensation lawsuits. From the data it is known that in the process of obtaining restitution, victims of criminal acts are hampered by ignorance about the merger of cases. In addition, the long and convoluted process is also an inhibition of restitution for victims of crime (Navira, 2014).

Restitution is actually important to give to victims of crime, but in this case the author will only focus on the child who is the victim of a sexual crime only. Therefore, based on the description finally encourages the curious author to know more about the fulfillment of restitution for children victims of sexual crimes in Makassar city.

\section{Metode}

The type of research used is empirical research. The research was conducted in Makassar city, precisely within the jurisdiction of Makassar Police, Makassar State Prosecutor's Office, Makassar District Court, Indonesian Women's Association for Justice Legal Aid Institute (LBH APIK Makassar) and Witness and Victim Protection Agency.

The data source in this study is primary data obtained directly from respondents, both in the form of in-person interviews and data collection in the form of document studies and secondary data obtained from literature research in the form of books, journals, magazines, newspapers, legislation and other documents relevant to the issue of restitution for children victims of sexual crimes.

The analysis used is an analysis of qualitative data that describes the data obtained, both from primary and secondary data then given an interpretation regarding the fulfillment of restitution rights for children victims of sexual crimes.

\section{Pembahasan}

\subsection{Implementation of restitution rights for children victims of sexual crimes in Makassar city}

The need to adequately provide legal protection to victims of crime is not only a national but international issue. The issue of justice and human rights in relation to criminal law enforcement is not a simple job to realize. One example of the lack of attention to justice and human rights issues in criminal law enforcement is related to the protection of the law against victims of crime (Nurini, 2017).

In public life, children are in a position to be vulnerable to various crimes, including sexual crimes (Abdul, 2013). Sexual crimes against children have become a familiar topic among society, 
this is evidenced by the increasing cases of sexual crimes against children every year. Victims of sexual crimes need special protection, both physically and mentally. So in addition to punishing perpetrators, all parties should also pay attention to the rights of victims of crime (Dien, 2016).

The need for protection and support for victims is a top priority that cannot be bargained for. In meeting these needs, the scope of protection and support and the forms of protection provided to victims must be thorough and ensure the protection of the rights of victims at every stage of the criminal justice system (Maharani, 2014).

Victims who suffer and are harmed by criminal law violations are often dissatisfied with the demands filed by prosecutors and/or verdicts handed down by judges because they are not considered in accordance with the value of victim justice (Fauzy, 2015).

Legal protection for victims of crime is part of the protection of society, can be realized through various forms, for example through restitution and compensation to victims, medical services and also in the form of legal aid (Dikdik and Elisatris, 2008).

For the victims themselves, acceptance of restitution is certainly also meaningful rather than just the imprisonment of the perpetrator. In addition, with the amount of money that the perpetrator must pay as restitution to the victim, it can also give a deterrent effect to the perpetrator (Andreas, 2017). On the other hand, there are still many who think that with the fall of criminal verdicts on the defendant, then justice for the victim has been automatically fulfilled even though it has only provided deterrent or retaliatory effect for the convicted and not necessarily restored the condition of the victim or the victim's family (Umi, 2016).

In restorative justice, restitution as a means of improvement of the parties, the role of victims and perpetrators of crimes is recognized both in the problem of solving the rights and needs of the victim, the perpetrator of the crime is encouraged to be held accountable. The accountability of the perpetrator is formulated as the impact of understanding the action and to decide the best (Syukri and Sutiawati, 2018).

Government Regulation number 43 of 2017 has explained that every child who is a victim of a crime is entitled to restitution, as for restitution in the form of damages for loss of wealth, compensation for suffering as a result of criminal acts and/ or reimbursement of medical and/or psychological care costs.

Based on the author's research obtained from Makassar Police, Makassar State Prosecutor's Office and Makassar District Court regarding data on sexual crimes against children over the past two years, the data of the results of the study can be shown in the following table:

Data on Child Sexual Crimes Cases in Makassar Year 2018-2019

\begin{tabular}{lccc}
\hline \multicolumn{1}{c}{ Agencies } & $\mathbf{2 0 1 8}$ & $\mathbf{2 0 1 9}$ & Total \\
\hline Makassar Police & 43 & 45 & 88 \\
Makassar State Prosecutor's Office & 14 & 17 & 31 \\
Makassar District Court & 14 & 17 & 31 \\
\hline
\end{tabular}

Source: Makassar Police, Makassar District Prosecutor, Makassar District Court

Based on the table, it can be seen that the rate of sexual crimes against children increases each year. In Makassar Police, cases of child sexual crimes in 2018 reached 43 cases and in 2019 there were an increase in cases up to 45 cases. While in the Makassar Prosecutor's Office and Makassar District Court, the number of cases of child sexual crimes has the same number, namely 14 cases in 2018 and 17 cases in 2019. 
Restitution rights for children of victims of sexual crimes: between protection and reresting

Siti Hudzifah Miftahul Jannah, Syamsuddin Muchtar, Hijrah Adhyanti Mirzana

Sexual Misconduct Restitution Application Data

Against Children 2018-2019

\begin{tabular}{cccl}
\hline Years & Police & Prosecutors & Total \\
\hline 2018 & 0 & 1 & 1 case \\
2019 & 0 & 0 & 0 case \\
\hline
\end{tabular}

Source: Makassar Police and Prosecutor's Office Makassar State

In 2018, there were 43 cases of child sexual crimes dealt with by Makassar Police. Of the 43 cases, none of the restitution applications were filed by victims in the investigation. Meanwhile, in the Makassar State Prosecutor's Office there are 14 cases of child sexual crimes dealt with and there is one case where the victim submits a restitution application. Meanwhile, in 2019, there is not a single case in either the Police Department or in the Prosecutor's Office applying for restitution.

The application for restitution was made at the prosecution stage and accompanied directly by the Witness and Victim Protection Agency (LPSK). LPSK is an institution that is authorized to provide protection to witnesses, victims and whistleblowers in all stages of the criminal justice process.

In order to obtain protection from LPSK, witnesses and/or victims must apply for protection in writing to LPSK. Such protection requests may be submitted at the initiative of witnesses and/ or victims or at the request of authorized officials. The protection application acceptance service is carried out by LPSK through the application acceptance division (Novita and Kenny, 2018).

Restitution can only be obtained if the victim a pleas for restitution, either at the investigation or prosecution stage. In addition, it can also be submitted through LPSK. So this restitution is not immediately accepted by the victim, but must apply in advance.

The process of assessing the amount of restitution application is carried out by LPSK offic- ers, namely indemnity assessors who in their work are guided by the internal rules of LPSK (SK Ketua LPSK No. 407/ 1.5.2.HSKR/LPSK/ 05/ 2018 on Instructions for The Implementation of Restitution by LPSK Officers) (Syahrial, 2020).

The calculation of losses of victims who apply for restitution is as follows: First Victim, 1) Element of loss assessment for loss of wealth (Article 3 letter a Government Regulation number 43 of 2017). Loss details: a) Loss on loss of income or income of parents of victims who worked as meatball traders during the legal process: Sales income per day Rp.3.500.000,- x 15 days = Rp.52.500.000,; b) Loss of school transfer fee amounting to Rp.500.000,- ; c) Loss of transportation costs and other costs incurred during the legal process amounting to Rp.500.000,-. 2) Element of assessment of medical and psychological care costs (Article 3 letter c Government Regulation number 43 of 2017). Loss details: a) 1) Physical suffering: The victim needs medical care costs for long-term recovery with medical measures to be taken such as: a. Cost of CT scan, ultrasound and MRI; b. Drug and outpatient or hospitalization costs; c. Examination of a specialist; d. Transportation costs in the framework of medical services. The amount is Rp.20.000.000,-. 2) Psychic suffering: a. Psychological counseling service fee Rp.250.000,-; b. Psychological therapy service fee Rp.250.000,-; c. Home visit transportation fee Rp.150.000,-; d. Counseling and psychotherapy for the victim and her mother will be performed once a week for 12 months, starting from March 2018 to March 2019.The total amount is Rp.76.800.000,-. The total value of the first victim's loss amounted to Rp.150.300.000,- (one hundred and fifty million one hundred and thirty thousand rupiah).

Second Victim, 1. Element of loss assessment for loss of wealth (Article 3 letter a Government Regulation number 43 of 2017). Loss details: 1) Loss on loss of income or income of the victim's parents who worked as a bread agent during the 
legal process: a. Sales income per day Rp.1.400.000,with a revenue share system of $17 \%$ for agents; $b$. Average net income per day rp.238.000,-; c. Loss of income during legal proceedings 17 days $x$ Rp.238.000,-. Total loss of Rp.4.046.000,-. 2) Loss of transportation costs and other costs incurred during the legal process amounting to Rp.500.000,. 2. Element of assessment of medical and psychological care costs (Article 3 letter c Government Regulation number 43 of 2017). Loss details: 1) Physical suffering: The victim needs medical care costs for long-term recovery with medical measures to be taken such as: a. Cost of CT scan, ultrasound and MRI; b. Drug and outpatient or hospitalization costs; c. Examination of a specialist; $d$. Transportation costs in the framework of medical services. The amount is Rp.20.000.000,-. 2) Psychic suffering: a. Psychological counseling service fee Rp.250.000,-; b. Psychological therapy service fee Rp.250.000,-; c. Home visit transportation fee Rp.150.000,-; d. Counseling and psychotherapy for the victim and her mother will be performed once a week for 12 months, starting from March 2018 to March 2019. The total amount is Rp.76.800.000,-.

The total value of the second victim's loss amounted to Rp. 101,346,000,- (one hundred and one million three hundred and forty-six thousand rupiah). (Source: Witness and Victim Protection Agency)

In this case, although the restitution request was granted by the court but the defendant did not pay the restitution to the victim. The defendant was sentenced to six years in prison and a six-month prison sentence in exchange for the restitution payment.

In practice, lpsk's role is to communicate to the defendant or through his legal counsel in order to carry out the court's ruling, but again there is no norm governing the power of force to carry out a restitution verdict (Shahrial, 2020).

The challenges of restitution are as follows: 1) Lack of attention to the ability of the perpetra- tor in the realization of restitution; 2) Sensitivity to use the authority of prosecution by ensuring the convicted will participate to make recovery to the victim through restitution payment; (Muhith, $2020)$; 3) The role of social workers is also very influential because those who are most in contact with the victim, from the beginning are called by investigators. (Rustiani, 2020); 4) Uneven law enforcement knowledge of the rights of the victim's child including restitution, so often restitution is ignored in the law enforcement process; 5) The vacancy of the arrangement regarding the implementation of restitution in the perpetrator is unwilling or unable to pay restitution, so that many cases of court rulings cannot be carried out (only the verdict on paper, cannot be executed) (Syahrial, 2020).

Based on the exposure, it can be noted that the implementation of restitution application application made by victims at the investigation stage of 2018 to 2019 is not fulfilled. This is because none of the victims applied for restitution at this stage of the investigation.

The implementation of restitution applications made by victims at the prosecution stage from 2018 to 2019 is not met. This is because only one victim applied for restitution at that stage of the prosecution. In addition, although the victim's restitution application was granted in court, the victim still did not get restitution from the perpetrator.

Therefore, it can be said that the implementation of restitution rights for children victims of sexual crimes has not been optimal, especially in makassar jurisdiction.

\subsection{The influence of law enforcement and vic- tims in the fulfillment of restitution rigts for children of victims ofsexual crimes in Makassar city}

Sexual crimes against children are no longer of the usual nature but victims should have maxi- 
mum protection and in them there must be fulfillment of the rights of the child who is the victim (Rosmiati, 2020).

In addition, the psychological factors of the perpetrator, the factors of the relationship between the perpetrator and the victim of sexual crimes as well as the environmental and social factors of individuals such as the consumption of alcoholic beverages and drugs are also the cause of the sexual crimes against children. However, not everyone who consumes alcohol and uses illegal drugs is the perpetrator of sexual crimes (Bambang, 2020).

In the fulfillment of restitution rights for children victims of sexual crimes certainly do not escape from law enforcement in its implementation. Law enforcement is the duty and responsibility of the community and judicial institutions consisting of the police, prosecutors, courts and advocacy agencies.

A very important part of the implementation of law enforcement is the role of law enforcement to look at position cases with all associations including those involved in a case (Sutan, 2006). The ineffectiveness of the law can be due to its vague or obscure laws, its inconsistent apparatus and/or its people who do not support the implementation of the law (Salim and Erlies, 2017).

Related to the fulfillment of restitution rights for children victims of sexual crimes, there are two influential factors in its fulfillment, namely the community factors consisting of the victim and the victim's own family as well as the law enforcement factors that are investigators and prosecutors who have the task of informing the victim of such restitution rights. The two factors will be explained as follows:

1. Community Factors (Victims and Victims' Families)

Community participation is greatly lacking in law enforcement. The lack of legal knowledge by the public is not separated from the lack of socialization of law enforcement officers (Laurensius, 2015). Victims have a strategic function in law enforcement, where victim reporting is the first step of any disclosure of a case. Thus, law enforcement can run its maximum if the victim participates in the implementation of law enforcement by law enforcement (Edi and Kristian, 2017).

Many of the losses that the victim's child suffered, were unable to return to school out of shame, were unable to socialize in the neighborhood and medical expenses that did little. In order for the right of restitution for the child of the victim of this sexual crime to be fulfilled, the victim and the victim's family must understand that there is restitution that can be obtained by the child who is the victim of a crime (Rosmiati, 2020).

The main problem in the fulfillment of restitution rights for children victims of sexual crimes due to child sexual crimes is a very strange case. Some people consider that sexual crimes are used as a right of autonomy and are private, others should not interfere and know it because it includes disgrace that must be covered up. For this reason, many cases of sexual crimes cannot be disclosed and the fulfillment of restitution rights for victims cannot be realized.

Restitution is difficult to apply because on the part of the victim, whether it is the parent or guardian, he argues that his child's virginity cannot be replaced and judged with money (Rabiah, 2020). Therefore, it is the duty of law enforcement to explain to the victim's parents that restitution is a form of recovery for the harm suffered by the child. Restitution is a substitute for hospital costs, replacement of transportation costs during the trial, replacement of consumption costs and replacement of daily income costs that cannot be met due to having to attend the trial (Rosmiati, 2020). The public should be psychologically aware 
of the prevailing laws and regulations. Law enforcement not only explains what the rules are but why they are created and what benefits the public will get (Amran, 2018). In addition, the basic truth of the restitution request submitted must be a direct result arising from the crime committed by the defendant and the amount of restitution can actually be proven by the prosecutor or the victim (Andi and Abd, 2014).

However, although there have been parties explaining this to the victim, this restitution will still not be met if the victim and his family continue to insist on not applying for restitution.

In addition to the public's ignorance of the right of restitution for children who are victims of crime, the lengthy process of having to complete some files is also the reason the victim and her family did not apply for restitution.

In the investigation and prosecution stage, victims can only apply for restitution no later than three days after notification of the right of a child to be a victim of a crime by an investigator or prosecutor.

Although the victim applied for restitution and was granted by the judge, there was still no forced effort for the perpetrator to pay the restitution to the victim. It can also make the victim think that there is no point in applying for restitution because even if the victim submits the restitution application and is granted, especially having gone through a long process, the victim will not get restitution from the perpetrator if the perpetrator refuses or is unable to pay the restitution fee (Rosmiati, 2020).

2. Law Enforcement Factors

Institutionally, institutions tasked with enforcing the law or law enforcement agencies are police, prosecutors, courts, correctional institutions and advocate's offices. But in terms of the apparatus called law enforcement are investigators, prosecutors, judges, correctional wardens and lawyers (Bambang, 2016).

The work of law enforcement officers institutionally is a mandate given by the law to each of these agencies to be able to carry out all its duties properly and properly so that the public will be able to feel the real impact of implementing the law enforcement system (Laurensius, 2015).

Based on interviews that have been conducted by writers with law enforcement such as investigators, prosecutors, judges and advocates, it turns out that there are still among those who do not know about the restitution rights for children victims of sexual crimes described in Government Regulation number 43 of 2017.

At the investigation or prosecution stage, the investigator or public prosecutor informs the victim of the right of the child who is the victim of a crime to obtain restitution and the procedure for filing it. This is clearly explained in Government Regulation number 43 of 2017. Based on interviews conducted by the author to advocates who have accompanied victims of sexual crimes, none of these victims have ever applied for restitution. In criminal proceedings, law enforcement officials never tell the victim or the victim's legal counsel about his right to apply for restitution. Although legal counsel has discussed restitution, investigators have suggested that the restitution application be made at the prosecutor's office. At the time of restitution request, law enforcement immediately processes it (Rosmiati, 2020).

From interviews with two prosecutors, the first prosecutor who has never included restitution in his prosecution emphasized that investigators who played a key role in informing the victim of the restitution rights because the first to deal with the victim was the inves- 


\section{Restitution rights for children of victims of sexual crimes: between protection and reresting}

Siti Hudzifah Miftahul Jannah, Syamsuddin Muchtar, Hijrah Adhyanti Mirzana

tigator. The second public prosecutor, meanwhile, once included restitution in his claim because the victim was immediately accompanied by LPSK.

Based on this, it is known that the lack of law enforcement knowledge about the restitution of children victims of sexual crimes so that they corner each other about who should convey that right first to the victim. But it is appropriate that both investigators and prosecutors inform the victim of the restitution rights. Based on the explanation of both factors, it can be seen that the role of the victim holds a great influence in the fulfillment of restitution rights for the child victim of sexual crimes. This is because even if law enforcement is supposed to inform the victim of the restitution, it is the victim who decides whether or not to apply for restitution.

\section{Simpulan}

Based on the results of the research conducted can be concluded that the implementation of restitution rights for children victims of sexual crimes in Makassar city is not fulfilled, this is evidenced from 30 cases of sexual crimes decided in court, there is only one case where the victim submits a restitution application and the victim does not obtain restitution from the perpetrator.

In the fulfillment of restitution rights for children of victims of sexual crimes, law enforcement and victims have influence. However, the role of the victim wields greater influence, this is because even if law enforcement is supposed to inform the victim of the restitution rights, it is the victim who decides whether or not to apply for restitution because restitution can only be obtained if the victim submits an application, not automatically accepted by the victim.

In order for the fulfillment of restitution rights for children victims of sexual crimes to be fulfilled, of course, the role of law enforcement and victims is required. Where law enforcement is supposed to represent the victim's interest in fulfilling the victim's sense of justice including the right to recovery through restitution submissions and notifying the victim of such restitution rights so that the victim knows his or her rights and can apply for restitution. In addition, clearer rules are needed about the consequences for perpetrators if they do not want or are unable to pay restitution to the victim. As for the victim as the harmed party, of course must understand well about its right in obtaining restitution from the perpetrator. So if law enforcement has informed the victim of that right, the victim should not ignore it and as much as possible apply for restitution in order for the victim to be compensated for what he suffered.

\section{Daftar pustaka}

Abdussalam dan Adri Desasfuryanto. 2014. Hukum Perlindungan Anak. Jakarta: PTIK.

Adawiyah, Rabiah Tul. 2020. Pekerja Sosial Dinas Sosial Makassar. Wawancara. Makassar.

Akub, M. Syukri dan Sutiawati. 2018. Keadilan Restoratif. Yogyakarta: Litera.

Aprilianda, Nurini. 2017. Perlindungan Anak Korban Kekerasan Seksual Melalui Pendekatan Keadilan Restoratif. Arena Hukum. Vol. 10 Nomor 2.

Arliman S, Laurensius. 2015. Penegakan Hukum dan Kesadaran Masyarakat. Yogyakarta: Budi Utama.

A.S., Alam dan Amir Ilyas. 2018. Kriminologi Suatu Pengantar. Jakarta: Kencana.

Dewi, Novita Prima dan Kenny Alam Fauzi. 2018. Laporan Tahunan 2018. Lembaga Perlindungan Saksi dan Korban.

Fadli, Andi Chaerul. 2018. 3.300 Kasus Kekerasan Terhadap Anak Terjadi di Sulsel. NewsRakyatku.com.

HS, Salim dan Erlies Septiana Nurbani. 2017. Penerapan Teori Hukum Pada Penelitian Tesis dan Disertasi. Jakarta: PT RajaGrafindo Persada. 


\section{Jurnal Cakrawala Hukum, Volume 12 No. 2 Agustus 2021}

ISSN PRINT 2356-4962 ISSN ONLINE 2598-6538

Idries, Abdul Mun'im. 2013. Membongkar Kekerasan Seksual dan Kejahatan Terhadap Anak. Jakarta: Noura Books.

Indah, Maya. 2014. Perlindungan Korban Suatu Perspektif Viktimologi dan Kriminologi. Jakarta: Kencana.

Kasih, Dien Kalpika. 2016. Efektivitas Pemberian Restitusi Terhadap Korban Tindak Pidana Berdasarkan Undang-Undang Nomor 31 Tahun 2014 Tentang Perlindungan Saksi dan Korban. Jurnal Idea Hukum. Vol. 4 No. 1.

Lukwira, Andreas Lucky. 2017. Restitusi Sebagai Pidana Tambahan yang Bermanfaat Bagi Pelaku dan Korban Tindak Pidana. Jurnal Deviance.

Mansur, Dikdik M. Arief dan Elisatris Gutom. 2008. Urgensi Perlindungan Korban Kejahatan. Jakarta: Raja Grafindo Persada.

Marabessy, Fauzy. 2015. Restitusi Bagi Korban Tindak Pidana: Sebuah Tawaran Mekanisme Baru. Jurnal Hukum dan Pembangunan. Vol. 45 No. 1.

Muin, Rustiani. 2020. Jaksa Penuntut Umum Kejaksaan Negeri Makassar. Wawancara. Makassar.

Nur, Muhith. 2020. Jaksa Penuntut Umum Kejaksaan Negeri Makassar. Wawancara. Makassar.

Nurcahyono, Bambang. 2020. Hakim Anak Pengadilan Negeri Makassar. Wawancara. Makassar.

Peraturan Pemerintah Republik Indonesia Nomor 43 Tahun 2017 Tentang Pelaksanaan Restitusi Bagi Anak Yang Menjadi Korban Tindak Pidana.

Rahmi, Umi. 2016. Implementasi Hak-Hak Korban Atas Kompensasi dan Restitusi Dalam Peradilan Pidana Vol. 1. Perpustakaan Nasional Republik Indonesia.
Sain, Rosmiati. 2020. Direktur Lembaga Bantuan Hukum APIK. Wawancara. Makassar.

Setiadi, Edi dan Kristian. 2017. Sistem Peradilan Pidana Terpadu dan Sistem Penegakan Hukum Indonesia. Jakarta: Kencana.

Sibuea, Harris Y.P. 2017. Persoalan Hukum Atas Restitusi Terhadap Anak Korban Tindak Pidana. Pusat Penelitian Badan Keahlian DPR RI. Vol IX Nomor 21.

Sjahdeini, Sutan Remy, et.al. 2006. Penegakan Hukum Di Indonesia. Jakarta: Prestasi Pustaka.

Sofyan, Andi dan Abd. Asis. 2014. Hukum Acara Pidana Suatu Pengantar. Jakarta: Kencana.

Sophia, Maharani Siti. 2014. Aksesibilitas Korban Kejahatan Dalam Sistem Peradilan Pidana. Jurnal Perlindungan Edisi 4 Vol. 1. Lembaga Perlindungan Saksi dan Korban.

Suadi, Amran. 2018. Sosiologi Hukum: Penegakan, Realitas dan Nilai Moralitas Hukum. Jakarta: Kencana.

Tueka, Navira Araya. 2014. Restitusi Bagi Korban Kejahatan Di Kabupaten Gowa (Suatu Tinjauan Viktimologis). Skripsi. Fakultas Hukum Universitas Hasanuddin.

Waluyo, Bambang. 2016. Penegakan Hukum Di Indonesia. Jakarta: Sinar Grafika.

Waluyo, Bambang. 2014. Viktimologi Perlindungan Korban dan Saksi. Jakarta: Sinar Grafika.

Wiryawan, Syahrial Martanto. 2020. Tenaga Ahli Lembaga Perlindungan Saksi dan Korban. Wawancara. Jakarta. 